\title{
Potrzeba zaangażowania lokalnych społeczności w przyszłość nieruchomego dziedzictwa kulturowego
}

\section{KEYWORDS}

tangible heritage, sustainable development, heritage value, heritage ownership, local community

\begin{abstract}
Aleksandra Ćwik, Potrzeba zaangażowania lokalnych społeczności w przyszłość nieruchomego dziedzictwa kulturowego [The need for local communities' involvement in the future of immovable cultural heritage]. Kultura - Społeczeństwo - Edukacja nr 2(18) 2020, Poznań 2020, pp. 351-365, Adam Mickiewicz University Press. ISSN 2300-0422. DOI 10.14746/kse.2020.18.13.1.

The discussion about cultural heritage versus development has been touched upon in many publications, and the role of cultural heritage is being deployed increasingly into transforming mere development efforts into efforts for sustainable development. By analysing recent literature which indicates the need for facilitation of cooperation between authorities and local communities, the theory of ownership and value of cultural heritage, and the close relationship between heritage protection and sustainable development, the article aims to discuss the role of the local community in managing monuments. The most relevant conclusions include the link between the protection of cultural heritage and the improvement of the quality of life of residents, their sense of identity and more durable bonds with the place of residence and the strife toward the achievement of local, sustainable development goals.
\end{abstract}

\section{Wprowadzenie}

Temat dziedzictwa kulturowego i rozwoju został poruszony w wielu publikacjach (m.in. Broński, 2006; Murzyn, 2002; Potoczek, 2000; Purchla, 2014). Coraz częś-

* ORCID: 0000-0002-5357-6922. 
ciej jest też podkreślana istotna rola dziedzictwa w niezbędnym już przekształceniu starań o rozwój w starania o rozwój zrównoważony, sustensywny i obecny we wszystkich trzech wymiarach funkcjonowania człowieka w państwie, tj. ekonomii, środowisku naturalnym oraz społeczeństwie (Gorzelak i in., 2018; Janikowski, Krzysztofek, 2009; Nocca, 2017; Purchla, 2000). Poniższy artykuł ma przywołać tę dyskusję w momencie, gdy negatywne skutki rozwoju niezrównoważonego w Polsce i na świecie stają się coraz bardziej odczuwalne. Poprzez analizę najnowszej literatury wskazującej na potrzebę facylitacji współpracy pomiędzy lokalnymi władzami a mieszkańcami, teorii własności i wartości dziedzictwa kulturowego oraz ścisłego związku pomiędzy ochroną dziedzictwa kulturowego i naturalnego a zrównoważonym rozwojem autorka podejmuje dyskusję na temat roli lokalnej społeczności w zarządzaniu zabytkami. Celem artykułu jest również podjęcie dialogu zainicjowanego w pracy Dziedzictwo kulturowe województwa wielkopolskiego w świetle danych Narodowego Instytutu Dziedzictwa. Przykład zabytków nieruchomych (Siniecka, Bogacka, 2018).

Wybuch pandemii COVID-19 na początku 2020 roku doprowadził do nakazanej społecznej izolacji prawie na całym świecie oraz fali refleksji na temat wspólnej przyszłości po kryzysie. Skutki recesji, która w kwietniu 2020 staje się nieuniknioną rzeczywistością, nieprędko przestaną być odczuwalne, jednak społeczny entuzjazm do zaniechania zgubnych nawyków takich jak konsumpcjonizm czy pogłębiające się społeczne nierówności stopniowo płowieje. Dziś niezwykle ważne jest uchwycenie momentu, tak aby rosnąca ludzka tęsknota bliskości i bezpieczeństwa stała się czynnikiem zmiany, a nie powodem do rozczarowania. Potrzeba bezpieczeństwa jest nie tylko drugą podstawową w piramidzie ludzkich potrzeb, ale również utożsamianą z potrzebą redukcji odczuwalnych braków (Maslow, 1943). Przywołanie tej nadużywanej już teorii ma na celu wzmocnienie przekazu, że motywacją jednostki jest działanie i rozwój w zaufanym środowisku, o czym nie powinno się zapominać podczas podejmowania decyzji na temat sensu promocji lokalnego aktywizmu, również kulturowego. To wiedza i doświadczenie sektora kreatywnego odgrywają ogromną rolę w komunikowaniu i diagnozowaniu zbiorowych wyzwań oraz motywowaniu do świadomego działania. Artyści i aktywiści kulturalni mają kompetencje krytycznej oceny ewolucji społecznej i inspiracji do działania (Kern, 2020). Również Global Heritage Fund (GHF) przypomina, że ożywienie gospodarcze może w przyszłości w dużej mierze zależeć od dziedzictwa kulturowego i społeczności, które do tej pory opierały swoje źródła utrzymania na jego ochronie (Global Heritage Fund, 2020). W przypadku gdy stworzenie środowiska sprzyjającego działalnościom społeczności lokalnych jest priorytetem lokalnej i ponadlokalnej polityki kulturalnej, efektem jest świetlana, choć nie zawsze 
powielająca tradycyjne rozwiązania przyszłość nieruchomego dziedzictwa narodowego lub regionalnego. Świadomość i postrzeganie własnego dziedzictwa kulturowego zależą w demokratycznych państwach, jak zauważa Skaldawski (2017), od dwóch równomiernie wpływających na siebie czynników. Opinia publiczna, praca aktywistów i pasjonatów będących częścią wspomnianych społeczności lokalnych oraz ich nacisk kierowany na władze na różnych szczeblach powinny formować decyzje dotyczące zarządzania dziedzictwem. Podobnie państwo poprzez edukację i kampanie społeczne ma obowiązek kształtować obiektywną lokalną i narodową odpowiedzialność za spuściznę kulturową.

\section{Przedmiot dyskusji}

Argumenty przedstawione w tym artykule oparte są na definicji dziedzictwa Laurajane Smith (2006), która opisuje je w najszerszy sposób jako proces angażowania się w przeszłość. Angażowanie, aktywne podjęcie odpowiedzialności to oś, wokół której autorka zbudowała swoje argumenty również w tym opracowaniu. Namacalne dziedzictwo kulturowe zostało w wyczerpujący sposób zdefiniowane w art. 1 Konwencji w sprawie ochrony światowego dziedzictwa kulturalnego i naturalnego (UNESCO, 1972) i w ten sam sposób będzie ono rozumiane w poniższych zestawieniach ${ }^{1}$.

Powołany w 2011 roku Narodowy Instytut Dziedzictwa jest głównym i kompleksowym źródłem wiedzy na temat stanu i liczby zabytków w Polsce. Najbardziej wyczerpującym pod tym względem zbiorem jest Rejestr zabytków nieruchomych, który liczy 78009 wpisów (stan na 8 stycznia 2020; Narodowy Instytut Dziedzictwa, 2020). Jak zauważyły Siniecka i Bogacka (2018) w swoim dogłębnym opracowaniu dziedzictwa kulturowego województwa wielkopolskiego, na podstawie tych samych danych, wyodrębnienie poszczególnych informacji na temat każdego rodzaju zabytku nieruchomego oraz stworzenie statystyk na podstawie materiałów

${ }^{1} \mathrm{~W}$ art. 1 Konwencji zostały wymienione następujące elementy dziedzictwa kulturowego: 1) zabytki: dzieła architektury, dzieła monumentalnej rzeźby i malarstwa, elementy i budowle o charakterze archeologicznym, napisy, groty i zgrupowania tych elementów mające wyjątkową, powszechną wartość z punktu widzenia historii, sztuki lub nauki; 2) zespoły: budowli oddzielnych lub łącznych, które ze względu na swą architekturę, jednolitość lub zespolenie z krajobrazem mają wyjątkową, powszechną wartość z punktu widzenia historii, sztuki lub nauki; 3) miejsca zabytkowe: dzieła człowieka lub wspólne dzieła człowieka i przyrody, jak również strefy, a także stanowiska archeologiczne mające wyjątkową, powszechną wartość z punktu widzenia historycznego, estetycznego, etnologicznego lub antropologicznego (UNESCO, 1972). 
NID jest niezwykle czaso- oraz pracochłonne² . Warto również pamiętać, że rejestr ten, tworzony na podstawie decyzji administracyjnych, które z kolei wydawane są „na przestrzeni lat w zmieniających się warunkach prawnych, doktrynalnych i organizacyjno-technicznych", jest bardzo dynamiczny i niejednorodny (Brudnicki, 2016). $\mathrm{Z}$ tego względu dane opracowane przez autorki tekstu Dziedzictwo kulturowe województwa wielkopolskiego w świetle danych Narodowego Instytutu Dziedzictwa. Przykład zabytków nieruchomych posłużą jako reprezentatywne $\mathrm{w}$ rozważaniach na temat potrzeby zaangażowania obywateli w ochronę dziedzictwa nieruchomego (Siniecka, Bogacka, 2018).

Według wniosków opracowanych przez autorki zabytki w województwie wielkopolskim nie są rozłożone równomiernie, a ich liczba i jakość rozkładają się na terenie całego województwa. Istnieją gminy, które mają wiele zabytków, a inne mniej. Najwięcej obiektów zarejestrowanych jako zabytek znajduje się w Poznaniu - jest to 9,26\% z 6987 na liście, czyli 647 obiektów. Podobnie sytuacja przedstawia się w trzech bogatych w zabytki powiatach: poznańskim (7,27\%, czyli 508 obiektów), kościańskim $(5,41 \%, 378)$ oraz gnieźnieńskim $(5,17 \%, 361)$. W powiatach, w których liczba zabytków jest najniższa, chodzieskim, ostrzeszowskim i w Koninie, można spotkać średnio 77 zabytków (Siniecka, Bogacka, 2018: 57-58). Kolejne spostrzeżenia na temat zasobów dziedzictwa kulturowego w województwie są następujące:

- gęstość występowania zabytków różni się na terenach różnych powiatów, gdzie średnia to 2,34 zabytku na $10 \mathrm{~km}^{2}$, a najwyższa gęstość dotyczy miast na prawach powiatów, są to Leszno, Poznań, Kalisz i Konin, w Lesznie zabytki są usytuowane najgęściej (Siniecka, Bogacka, 2018: 57-59);

- najczęściej spotykane zabytki to budynki mieszkalne, za którymi plasują się te o charakterze sakralnym, zieleń, budynki folwarczne oraz rezydencjonalne; najrzadziej spotykanym typem zabytku w województwie wielkopolskim są zamki (Siniecka, Bogacka, 2018: 59);

- najwięcej zabytków w każdym powiecie pochodzi z XIX wieku, piętnaście $\mathrm{z}$ trzydziestu pięciu powiatów ma na swoim terenie również zabytki najstarsze datowane na okres przed drugą połową XIII wieku; w każdym powiecie znajdują się obiekty, których wiek jest nieznany (Siniecka, Bogacka, 2018: 62);

${ }^{2}$ Narodowy Instytut Dziedzictwa dzieli zabytki nieruchome w następujący sposób: krajobraz kulturowy, układ przestrzenny, mała architektura, architektura sakralna (kościół, cerkiew, meczet, synagoga, kaplica, klasztor), architektura obronna (budynek bramny, twierdza, mur obronny, zamek), architektura przemysłowa (fabryka, most, kopalnia, infrastruktura kolejowa, wiatrak, młyn), zespół parkowo-ogrodowy (ogród, pawilon parkowy, park, aleja), zespół rezydencjonalny (pałac, dwór), budynek użyteczności publicznej (ratusz, łaźnia, karczma), budynek mieszkalny (kamienica, chałupa, willa), budynek gospodarczy, miejsce pamięci, cmentarz, inne. Źródło: https://zabytek.pl. 
- według autorek geneza różnic w liczbie i typie zabytków jest związana z „[... jakością gleb, występowaniem bogactw naturalnych, przebiegiem szlaków komunikacyjnych i handlowych, kształtowaniem się granic państwa, administracji lokalnej i kościelnej, powstawaniem centrów elitarnych (w tym stolicy regionu), funkcjonowaniem uniwersytetu lub ważnego miejsca kultu [...], przynależnością Wielkopolski do różnych zaborów” (Siniecka, Bogacka, 2018: 60-62).

To liczbowe zestawienie przedstawia przykładowy stan rozmieszczenia i gęstości zabytków w jednym z polskich regionów, jednak liczba obiektów zabytkowych nie zawsze pokrywa się z ich wartością. Jeżeli w pewnej okolicy jest ich relatywnie niewiele, nie oznacza to, że nie cieszy się ona popularnością wśród turystów lub dużym zainteresowaniem badaczy. Liczba i wartość obiektów zabytkowych rozkładają się nierównomiernie i niekoniecznie są od siebie zależne, dlatego tak trudno jest oczekiwać od samorządów aktywnego zaangażowania w poprawę losu każdego obiektu na terenie ich wpływów, tym bardziej że pojęcie wartości dziedzictwa kulturowego jest zbiorem wielu czynników, z których nie wszystkie są obiektywne. Genezy wartości dziedzictwa kulturowego można podzielić na relatywne, a więc takie, które zależne są od pewnych dynamicznych norm uznanych w poszczególnych społecznościach, oraz uniwersalne, czyli obiektywne i niepodważalne przez normy kulturowe.

Tabela 1. Zestawienie elementów składających się na nadawanie wartości obiektom dziedzictwa kulturowego

\begin{tabular}{|c|c|}
\hline $\begin{array}{l}\text { Relatywne postrzeganie wartości dziedzictwa } \\
\text { kulturowego }\end{array}$ & $\begin{array}{l}\text { Uniwersalne postrzeganie wartości dziedzictwa } \\
\text { kulturowego }\end{array}$ \\
\hline $\begin{array}{l}\text { - Wymiar estetyczny } \\
\text { Jest subiektywną oceną piękna, indywidualnego } \\
\text { doświadczenia estetycznego każdego z odbiorców. } \\
\text { - Wymiar symboliczno-skojarzeniowy } \\
\text { Związany z historią, tradycjami i normami kultu- } \\
\text { rowymi poszczególnych społeczności. Wpływa na } \\
\text { wzmocnienie postaw patriotycznych, tożsamości } \\
\text { kulturowej lub narodowej czy poczucia odpowie- } \\
\text { dzialności za lokalne tradycje lub miejsce zamiesz- } \\
\text { kania. }\end{array}$ & $\begin{array}{l}\text { - Wymiar finansowy } \\
\text { Zakłada, że dziedzictwo to towar, a zabytki mają } \\
\text { pewną wartość monetarną na potencjalnym rynku } \\
\text { zbytu. } \\
\text { - Wymiar funkcjonalny (użytkowy) } \\
\text { Zakłada, że dziedzictwo w formie na przykład } \\
\text { obiektów historycznych może być wykorzysty- } \\
\text { wane (konsumowane) zarówno współcześnie, jak } \\
\text { i w przyszłości. } \\
\text { - Wymiar symboliczny } \\
\text { Zakłada, że dziedzictwo jest wartościowe nie ze } \\
\text { względów ekonomicznych, jednak jako wartość } \\
\text { sama w sobie, jako kapitał kulturowy całej ludz- } \\
\text { kości. } \\
\text { - Wymiar artystyczny } \\
\text { Nie jest subiektywny, ale oparty na naukowej oce- } \\
\text { nie pewnego warsztatu artystycznego. Oparty na } \\
\text { ocenie formalnej. }\end{array}$ \\
\hline
\end{tabular}

Źródło: Kobyliński, 2011. 
Według porównania (tabela 1) czynników wpływających na postrzeganie obiektów zabytkowych, na ich wartość, a więc także oddziaływanie na odbiorców składa się wiele elementów, jednak nie wszystkie są tak samo istotne dla każdej grupy odbiorców, co sugeruje pytanie „Do kogo należy dziedzictwo?”, a w kontekście tego opracowania bardziej zasadne jest pytanie „Do kogo należą zabytki w moim regionie?".

Jednym ze sposobów na analizę skomplikowanej sytuacji własności obiektów wpisanych do rejestru zabytków, a więc zrozumienie, jak rozkłada się bezpośrednia odpowiedzialność nad zabytkami w Polsce, jest zebranie danych dotyczących wnioskodawców o dofinansowanie prac konserwatorskich. Poniżej (tabela 2) przedstawione są dane udostępnione przez Ministerstwo Kultury i Dziedzictwa Narodowego w formie wyników dwóch naborów na dotacje w ramach programu MKiDN „Ochrona zabytków” na rok 2019. Istotny jest główny cel udzielanego wsparcia zawarty w regulaminie jako „zachowanie materialnego dziedzictwa kulturowego, realizowane poprzez konserwację i rewaloryzację zabytków nieruchomych i ruchomych oraz ich udostępnianie na cele publiczne" (Ministerstwo Kultury i Dziedzictwa Narodowego, 2019).

Tabela 2. Analiza profilów wnioskodawców o wsparcie ochrony zabytków z budżetu MKiDN w ramach programu „Ochrona zabytków” na rok $2019^{3}$

\begin{tabular}{|l|r|r|r|r|r|r|r|r|}
\hline \multicolumn{1}{|c|}{ Wnioskodawca } & \multicolumn{2}{|c|}{$\begin{array}{c}\text { Prywatny wnios- } \\
\text { kodawca }\end{array}$} & \multicolumn{2}{|c|}{$\begin{array}{c}\text { Instytucje pań- } \\
\text { stwowe }\end{array}$} & \multicolumn{2}{|c|}{$\begin{array}{c}\text { Instytucje koś- } \\
\text { cielne }\end{array}$} & \multicolumn{2}{|c|}{$\begin{array}{c}\text { Razem (w tym } \\
\text { wnioski rozpatrzo- } \\
\text { ne pozytywnie) }\end{array}$} \\
\hline Nabór & Nabór I & Nabór II & Nabór I & Nabór II & Nabór I & Nabór II & Nabór I & Nabór II \\
\hline $\begin{array}{l}\text { Liczba złożonych } \\
\text { wniosków (udział } \\
\text { procentowy) }\end{array}$ & $\begin{array}{r}286 \\
(15,9 \%)\end{array}$ & $\begin{array}{r}131 \\
(20,6 \%)\end{array}$ & $\begin{array}{r}219 \\
(12,1 \%)\end{array}$ & $\begin{array}{r}125 \\
(19,7 \%)\end{array}$ & $\begin{array}{r}1299 \\
(72 \%)\end{array}$ & $\begin{array}{r}379 \\
(59,7 \%)\end{array}$ & $\begin{array}{r}1804 \\
(530)\end{array}$ & $\begin{array}{r}635 \\
(87)\end{array}$ \\
\hline
\end{tabular}

Źródło: opracowanie własne na podstawie danych Ministerstwa Kultury i Dziedzictwa Narodowego, 2019.

${ }^{3}$ Budżet programu wg regulaminu to $112125000 \mathrm{zł}$, a suma dotacji przyznanych podczas obu naborów to 135432952 zł (Ministerstwo Kultury i Dziedzictwa Narodowego, 2019).

${ }^{4}$ W tym przedsiębiorstwa prywatne, osoby fizyczne, spółdzielnie i wspólnoty, ale również fundacje oraz przedsiębiorstwa będące dzierżawcami zabytku należącego do lokalnego samorządu, np. gminy, stąd tabela przedstawia właścicieli oraz podmioty odpowiedzialne za zabytki. W przypadku gdy właścicielem jest organ państwowy, a dzierżawcą osoba fizyczna lub prywatne przedsiębiorstwo, priorytet dany jest dzierżawcy jako podmiotowi o bezpośredniej odpowiedzialności i zaangażowaniu w ochronę obiektu.

${ }^{5} \mathrm{~W}$ tym organy samorządowe oraz publiczne instytucje kultury, takie jak muzea, biblioteki, teatry czy domy kultury. 
Pomimo różnorodności podmiotów aktywnie zarządzających dziedzictwem, a więc tych odpowiedzialnych za ochronę obiektów, a w tym staranie się o środki na ich konserwacje czy udostępnianie ich na cele publiczne, trudno jest dyskutować na temat własności względem zabytków. Jednym z powodów jest przedstawiony w tabeli 1 relatywny wymiar nadawania wartości obiektom zabytkowym. Dziedzictwo ma tym większą wartość, im większa jest społeczność, na którą wpływa. Tym samym, jak w swoim artykule na temat własności dziedzictwa kulturowego pisze Kobyliński (2011: 41), „problem własności dziedzictwa kulturowego nie jest zatem problemem prawnym (chociaż często na gruncie prawa podejmowane są próby rozwiązania tego problemu), ale etycznym. Z punktu widzenia rozwoju kulturowego ludzkości nie jest ważne, kto posiada materię dziedzictwa kulturowego, ale kto i w jaki sposób ma prawo korzystania z jego niematerialnych wartości”.

\section{Potrzeba zaangażowania lokalnej społeczności}

Często zaangażowanie we wspólne życie lokalnej społeczności oraz relatywnie duża wiedza na temat otoczenia lub chęć zdobywania takiej wiedzy są głównymi determinantami wpływającymi na wzmocnienie więzi psychospołecznych mieszkańców z ich miejscem zamieszkania (Michalska, 2002). Co więcej, poziom mobilizacji w gminach, czyli aktywni i wywierający oddolny nacisk mieszkańcy motywują władze lokalne do samorozwoju w dziedzinie zarządzania i innowacji tak, aby stale odpowiadać na działania organizacji pozarządowych, konkurencyjnych partii lub lokalnych mediów (Hryniewicz, 2004: 68). W podobnym duchu, z inicjatywy fińskiej gałęzi Europa Nostra (EuNoF), w 2018 roku powstała publikacja Dziedzictwo jest nasze (Heritage is Ours). Prezentując dobre praktyki i przykłady, w których mieszkańcy aktywnie wpłynęli na decyzje administracyjne dotyczące ich lokalnego dziedzictwa, autorzy podzielili typy partycypacji mieszkańców na dwie grupy w zależności od genezy inicjatywy.

Według wielce uproszczonego podziału pierwsza grupa to inicjatywy oddolne, a druga to te zaproponowane przez ciała administracyjne, chodzi o inicjatywy, które są odgórne, ale nie są narzucone. Głównym założeniem promocji współpracy mieszkańców z władzą lokalną jest wzajemne słuchanie postulatów i współpraca nieoparta na hierarchii. Narzędziami do osiągnięcia tak zrównoważonej współpracy są mapowanie (place mapping) oraz planowanie kulturowe (cultural planning) (Halme i in., 2018). Ghilardi (2018) tłumaczy oba narzędzia jako niezbędne w nowym nurcie planowania przestrzeni opartym na systemie relacji, który jest indywidualny dla każdego - w przypadku jej badań - miasta. Przykładem 
skutecznej implementacji tej metody w kontekście ochrony i promocji regionalnego dziedzictwa kulturowego jest czeski Zlin. Dzięki współpracy z uniwersytetem, regionalną izbą handlową i lokalnymi przedstawicielami przemysłu kreatywnego udało się tam stworzyć strategię, w wyniku której zaniedbane dziedzictwo przemysłowe przeszło transformację i jako miejsce zrzeszające firmy kreatywne specjalizujące się w projektowaniu i nowych technologiach stało się wizytówką regionu (Ghilardi, 2018: 106). Praktyczne narzędzia, za pomocą których autorka obrazuje swoje podejście do planowania przyszłości przestrzeni, a w tym dziedzictwa kulturowego, i które bazują na unikalnym kulturowym DNA danego miejsca, to m.in.:

- analiza źródeł wtórnych, w tym istniejących planów i strategii, oraz danych na temat stanu gospodarki miejsca i lokalnych metod rządzenia;

- mapowanie wyjątkowości miejsca, w tym percepcji wewnętrznej i zewnętrznej, obrazowanie w mediach, tworzenie map myślowych mieszkańców oraz map ducha miejsca, narracji miejsca oraz sposobu jego odczuwania;

- mapowanie tożsamości społecznej, w tym aktualnej dynamiki przemysłowej i gospodarczej, typy umiejętności wśród mieszkańców, wzory relacji między mieszkańcami, poziomu różnorodności kulturowej i stylu życia oraz poziomu wykształcenia;

- mapowanie idei (mind mapping), w tym praca nad nowymi politykami społecznymi, uczenie się i rozwój na podstawie przypadków i dobrych praktyk $\mathrm{z}$ innych miast, wsparcie wdrażania niestandardowych mechanizmów kreatywnego zarządzania;

- jakościowe mapowanie lokalnych zasobów kulturowych i kreatywnych, w tym diagnostyka łańcucha wartości w branżach kreatywnych, mapowanie klastrów, ocena infrastruktury kulturalnej i rekreacyjnej, ocena aktywności i różnorodności kulturowej, ocena konsumpcji kultury i aktywnej partycypacji (Ghilardi, 2018: 105).

Aktywizacja lub umożliwienie partycypacji mieszkańców w planowaniu zagospodarowania czy ochrony zabytków mają - oprócz powyżej wymienionych skutków takich jak poczucie sprawczości i silniejsze więzi z miejscem zamieszkania - również inne konsekwencje, z którymi pogodzili się już specjaliści w dziedzinie dziedzictwa kulturowego w Wielkiej Brytanii czy Stanach Zjednoczonych. Zaangażowanie mieszkańców w podejmowanie decyzji pozwala na sprawiedliwszą i rozsądną negatywną selekcję, która jest koniecznością (Kobyliński, 2011: 26). Przeprowadzone w 2017 roku przez NID oraz Instytut Socjologii Uniwersytetu Jagiellońskiego badania w ramach projektu „DoM - Dziedzictwo obok Mnie” pozwoliły na spojrzenie ilościowe na stosunek Polaków do dziedzictwa. Wyniki badań można uznać za dobrze rokujące, ponieważ mimo różnic wynikających z wie- 
ku i poziomu wykształcenia respondentów zdecydowana większość badanych odczuwa istotność dziedzictwa kulturowego w życiu swojej społeczności oraz całego narodu. Na przykład 85,3\% pytanych uznało dziedzictwo kulturowe za ważne dla Polski jako społeczeństwa, a 77,2\% dla społeczności lokalnych. Co więcej, 89,7\% Polaków postrzega dziedzictwo kulturowe jako czynnik, który sprawia, że miejsce zamieszkania może być wyjątkowe. Nie zanotowano również wyraźnych różnic dotyczących tego, jak mieszkańcy miast i wsi rozumieją wpływ dziedzictwa na jakość życia lokalnej społeczności. Zdecydowana większość odpowiedzi była afirmatywna (82,6\% na wsi, 89,2\% w miastach do 50 tys. mieszkańców, 77,5\% w miastach 50-200 tys. oraz 90\% w miastach powyżej 200 tys.) (Fortuna-Marek, Stępnik, 2017: 25-29).

\section{Dziedzictwo kulturowe a zrównoważony rozwój}

Czy w dobie pandemii mającej poważne skutki, która jest jednak pochodną ocieplającego się klimatu i narastających wyzwań z tym związanych, czy w takich warunkach warto kierować czas i energię na dyskusję o ochronie świadków przeszłości? Niezwykle kluczowe jest wyartykułowanie ważnej roli ochrony lokalnego dziedzictwa - które niekoniecznie dzieli się na naturalne i kulturowe, ale często występuje jako nierozerwalne zespolenie obu form - w walce o stabilną przyszłość.

Na potrzeby poniższych rozważań autorka posługiwać się będzie rozumieniem „zrównoważonego rozwoju” sformułowanym w 1987 roku przez Światową Komisję ds. Środowiska i Rozwoju (World Commission on Environment and Development) w raporcie „Nasza wspólna przyszłość” („Our Common Future”) ${ }^{6}$. Komisja Brundtland zakłada, że obecne pokolenie powinno dążyć do polepszenia środowiska naturalnego oraz sytuacji społecznej oraz ekonomicznej lokalnie i globalnie w taki sposób, aby otrzymany stan stał się obowiązującą, niezmienną normą. Zrównoważony rozwój to równomierne zaspokajanie potrzeb ludzkich na całym świecie w sposób, który nie ograbia przyszłych pokoleń z tych samych bogactw naturalnych i kulturowych, z których korzysta się dziś (Nocca, 2017; ONZ, 1987).

Minęła dekada od centralnej w tej dziedzinie publikacji Polskiego Komitetu ds. UNESCO Kultura a zrównoważony rozwój (Janikowski, Krzysztofek, 2009), jednak wiele postulatów w niej zawartych wciąż nie zostało zrealizowanych. Przykładami mogą być: potrzeba edukacji estetyki przestrzennej (Krzysztofek, 2009: 45), która - gdy jest na wysokim poziomie - wpływa pozytywnie na konkurencyj-

\footnotetext{
${ }^{6}$ Raport dostępny w języku angielskim: Organizacja Narodów Zjednoczonych, 1987.
} 
ność regionów zarówno w postrzeganiu ich mieszkańców, jak i osób z zewnątrz, czy wspomniana już potrzeba ochrony środowiska kulturalnego i przyrodniczego jako całości, w sposób zintegrowany (Myczkowski, 2009: 65-86). Publikacja oparta na dokumentach UNESCO, na istotnej w kontekście tego tekstu Konwencji w sprawie ochrony i promowania różnorodności form wyrazu kulturowego (spisana w 2005 roku, a ratyfikowana przez Polskę w 2007), została stworzona m.in. $\mathrm{w}$ celu promocji kultury jako istotnego czynnika w rozwoju państwa i budulca demokracji. Dzięki różnorodności kulturowej i silnej tożsamości kulturowej społeczeństwa możliwe jest oparcie się negatywnym skutkom globalizacji, które mogą stać w sprzeczności z ideą zrównoważonego rozwoju. Jak zauważa Krzysztofek (2009: 58), „jedynie w regionach i społecznościach o silnej tożsamości kulturowej (jak na Podhalu) te regionalizmy w żywieniu przetrwały, nie tylko z potrzeby promocji, ale także codziennego życia”. Dzięki temu kwitnąć mogą lokalne przedsiębiorstwa, a społeczeństwo, które unika śmieciowego jedzenia dostępnego w sieciach fast food, jest zdrowsze.

Dziedzictwo materialne i niematerialne, w tym budynki, krajobrazy czy tradycje i zwyczaje, jest bezpośrednio formułowane przez historyczne narracje i mity narodowe. Unikalny dla każdego narodu i każdej społeczności kolaż, mieszanka tradycji i namacalnego dziedzictwa, tworzy coś, co Geneviève Zubrzycki (2017: 193-195) nazywa narodowym sensorium (national sensorium), które pozwala obywatelom na faktyczne odczuwanie i utożsamianie się z konceptem narodowości, który - jak twierdzi autorka - bez sensorium byłby jedynie abstrakcją. Równocześnie dziedzictwo namacalne jest jednym z najbardziej konwencjonalnych wyrazów lokalnej kultury. Jak zauważa Broński (2006), może funkcjonować jako wizytówka regionu lub atrakcja turystyczna i tym samym pozytywnie wpływać na rozwój ekonomiczny swojej małej „ojczyzny”. Co więcej, turystyka kulturowa w krajach Europy Środkowej ma potencjał na zainteresowanie sobą zagranicznych zwiedzających. Tym samym ujawnia się wielki atut turystyki kulturowej, tj. towarzyszy ona poznaniu i krajoznawstwu, czyli również promocji w przypadku przyjezdnych turystów (Kozak, 2009: 78-79). Jednak nie każdy zabytek lub miejsce o istotnych walorach historycznych i kulturowych jest wystarczająco atrakcyjne, aby zachęcić rzesze turystów, i nie każdy też powinien być otwarty dla zwiedzających wystarczająco często, aby nie tylko pokryć koszty swojego utrzymania, ale również wesprzeć lokalną gospodarkę. Innymi słowy, które padły również w pracy Bojańczyka (2019), niektóre obiekty historyczne zmuszone są zarabiać na swoje utrzymanie i przyszłość, tymczasem „[...] to mógłby zapewnić państwowy mecenat, który wyjmowałby kluczowe dziedzictwo spod reguł rynkowych, które doprowadziły np. do organizowania w Wilczym Szańcu pojedynków paintballowych”. 
Aby powyższe rozważania połączyć ze wspomnianą definicją zrównoważonego rozwoju Komisji Brundtland, warto przywołać przykłady, w których zaniedbanie namacalnego dziedzictwa kulturowego okazało się nieodwracalnym błędem dopiero w perspektywie historycznej oraz aktualnie dyskutowanych przestrzeni, w których ochrona i konserwacja kultury przenika się z ochroną środowiska przyrodniczego. W 1980 roku amerykańska firma motoryzacyjna General Motors zdołała przekonać władze Detroit do przekazania jej całego osiedla położonego na granicy miasta i przedmieść oficjalnie zwanych Hamtramck, a nieoficjalnie i dużo częściej Poletown. Pomimo aktywnych protestów mieszkańców dokładnie 1500 domostw, 144 małe przedsiębiorstwa oraz 16 kościołów, wszystko wybudowane i utrzymywane przez polską mniejszość, zrównano z ziemią, aby ustąpić miejsca nowej fabryce samochodów GM. W listopadzie 2018 roku ostatnia z dwóch fabryk na tym terenie została zamknięta, a ponad 1500 osób straciło pracę. Dziś władze Detroit zastanawiają się, czy zniszczenie Poletwon przyniosło zamierzone efekty, to jest wprowadzenie innowacji i rozwój gospodarczy regionu. Amy Crawford (2018) wskazuje na liczbowe podsumowanie skutków relokacji mieszkańców osiedla. Przed 1980 rokiem osiedle dawało pracę około 4200 mieszkańcom. Prowadzili oni zwykle małe przedsiębiorstwa, które czasami funkcjonowały w tym samym miejscu od początku XX wieku. Tymczasem budynek fabryki, który aktualnie jako zabytek dziedzictwa industrialnego czeka na zagospodarowanie, był siedzibą dla 3000 pracowników (Crawford, 2018). W tym miejscu należy zaznaczyć, że przykład ten został przytoczony nie ze względu na pochodzenie mieszkańców osiedla, ale jako wyraźny przykład działań, które doprowadziły do potrzeby zdefiniowania pojęcia zrównoważonego rozwoju.

Podobnie, choć ten bardzo często przywoływany przykład dotyczy większej skali, potraktować należy zaniedbanie polskiej architektury drewnianej. Straty dotyczą szczególnie architektury małej, mieszkalnej oraz użyteczności publicznej, ponieważ między innymi dzięki wpisom na listę światowego dziedzictwa UNESCO (sześć drewnianych kościołów w Małopolsce i na Podkarpaciu wpisanych w 2003 roku) architektura sakralna cieszy się międzynarodową renomą i popularnością wśród zwiedzających. Do tej kategorii należą też m.in. drewniane kościoły Śląska Opolskiego ${ }^{7}$. Jednak jak czytamy w publikacji Drewniany Skarb. Chroniąc dziedzictwo, kreujemy przyszłość, „w chwili obecnej tradycyjne budownictwo drewniane przechodzi do przeszłości. Rzadkością są już wiatraki, młyny wodne, kuźnie, karczmy, drewniane budynki w wiejskiej zagrodzie, stąd też istnieje potrzeba opisania

7 Prezentacja kościołów w formie wirtualnej kolekcji została stworzona przez Narodowy Instytut Dziedzictwa oraz udostępniona za pośrednictwem portalu zabytek.pl, https://zabytek.pl/pl/ kolekcje/koscioly-drewniane-slaska-opolskiego. 
i ocalenia tego, co jest jeszcze możliwe. Każdy zachowany drewniany obiekt jest nie tylko świadectwem tradycyjnego budownictwa drewnianego, ale również źródłem wiedzy o zwyczajach, kulturze, historii regionówi narodów" (Pietrasiewicz, 2016:8). Dowiadujemy się również o roli ambasadorów ochrony dziedzictwa drewnianego: „[...] pokazujemy funkcję, jaką pełniło i nadal może pełnić drewno w dawnej architekturze polskiej. Prezentujemy zachwycającą jednorodność i harmonię architektury drewnianej ze środowiskiem przyrodniczym. Szukamy odpowiedzi na pytanie, skąd brały się unikalny charakter drewnianych domów i uroda małych miasteczek z ich drewnianą zabudową" (Pietrasiewicz, 2016: 9).

W odpowiedzi na obserwacje Lowenthala (1998), że nie istnieje aspekt natury, na który działalność człowieka by nie wpływała, jak również nie ma takiego obiektu, na którym swojego odcisku nie pozostawiłaby natura, można z powodzeniem twierdzić, że ochrona dziedzictwa kulturowego przenika się z ochroną dziedzictwa naturalnego. Negatywny wpływ zmian klimatu na światowe dziedzictwo został potwierdzony już w sposób jak najbardziej empiryczny. Co więcej, społeczności najbardziej narażone to te, które najmniej przyczyniają się do emisji gazów cieplarnianych do atmosfery. Raporty ostatnich lat wskazują również na tym razem pozytywne oddziaływanie $\mathrm{w}$ odwrotnym kierunku. Ochrona i promocja dziedzictwa kulturowego pozwala w praktyczny sposób hamować skutki kryzysu klimatycznego poprzez m.in. propagowanie gospodarki o obiegu zamkniętym, renowację i restaurację budynków, aby uniknąć nowych zabudowań, korzystanie $\mathrm{z}$ lokalnych materiałów o niskim śladzie węglowym oraz z autochtonicznych rozwiązań i technologii (ICOMOS, 2019; KE, 2019). W końcu, w kwietniu 2020, Europa Nostra, czyli europejska organizacja powołana w celu wspierania społeczeństwa obywatelskiego w ochronie dziedzictwa, wraz z ICOMOS (The International Council on Monuments and Sites), rozpoczęła działania na rzecz uwzględnienia roli ochrony dziedzictwa kulturowego w założeniach ambitnego planu European Green Deal (EGD) ${ }^{8}$. Planowana publikacja European Heritage Green Paper ma zwrócić uwagę na potrzebę uzupełnienia EGD, którego zasadniczym celem jest utrzymanie globalnego wzrostu temperatury na poziomie 1,5 stopnia Celsjusza, o aspekt dziedzictwa kulturowego (Europa Nostra, 2020) ${ }^{9}$.

\footnotetext{
${ }^{8}$ Cele nowej polityki promowanej jako European Green Deal są dostępne na portalu Komisji Europejskiej, https://ec.europa.eu/info/strategy/priorities-2019-2024/european-green-deal_en.

${ }_{9}$ Istotny w tych rozważaniach jest fakt, że Europa Nostra jest członkiem sieci Climate Heritage (http://climateheritage.org/), która została stworzona w celu facylitacji i wsparcia działań jej członków aktywnych w dziedzinie ochrony dziedzictwa kulturowego na rzecz osiągnięcia celów porozumienia paryskiego z 2015 roku.
} 


\section{Podsumowanie rozważań}

Celem rozważań była analiza wpływu zaangażowania mieszkańców w podejmowanie decyzji na temat przyszłości zabytków obecnych w miejscu ich zamieszkania. Do najważniejszych spostrzeżeń należy powiązanie ochrony dziedzictwa kulturowego z poprawą jakości życia mieszkańców, ich poczucia tożsamości i więzi z miejscem zamieszkania oraz z osiąganiem lokalnych celów zrównoważonego rozwoju. Co więcej, uznanie niehierarchicznej współpracy ze społecznością lokalną prowadzi do zrównoważonego planowania przestrzennego oraz tworzenia skutecznych strategii dla regionów. W końcu zachęcanie mieszkańców do aktywnego działania jest w dużej mierze poważnym zadaniem dla władz. Powinno się ono przejawiać w edukacji, kampaniach społecznych i regularnych konsultacjach. Jest to też zadanie, które w długoterminowej perspektywie przynieść może pozytywne skutki w postaci równomiernie rozłożonej odpowiedzialności za dziedzictwo kulturowe regionów oraz przywiązanie mieszkańców do miejsca zamieszkania, które jest w ich postrzeganiu konkurencyjne i w którym czują się bezpiecznie.

\section{Bibliografia}

Bojańczyk F. (2019), Polskie dziedzictwo, czyli jak sensowniej zarządzać naszymi zabytkami. Ablogeracja. O mieście, Europie Środkowej i dziedzictwie, http:// ablogeracja.pl/?m=201912.

Broński K. (2006), Rola dziedzictwa kulturowego w rozwoju lokalnym. Doświadczenie polskie doby transformacji (po 1989 r.), „Zeszyty Naukowe Akademii Ekonomicznej w Krakowie”, nr 706, s. 7-26.

Brudnicki J. (2016), Stwierdzenie nieważności decyzji o wpisie do rejestru zabytków, „Ochrona Zabytków”, nr 2, s. 69-104, http://cejsh.icm.edu.pl/cejsh/element/bwmeta1.element.desklight903e9701-5e71-406a-b8a2-8aa7c472feb6.

Crawford A. (2018), Can Poletown Come Back After a General Motors Shutdown?, https://www. citylab.com/equity/2018/12/poletown-history-general-motors-hamtramck-shutdown/577678/.

Europa Nostra (2020), Collaboration launched on a "European Heritage Green Paper", https://www. europanostra.org/collaboration-launched-on-a-european-heritage-green-paper/.

Fortuna-Marek A., Stępnik K. (2017), Komponenty postaw Polaków wobec dziedzictwa kulturowego, w: Dziedzictwo kulturowe w badaniach. Polacy wobec dziedzictwa. Raport $z$ badań społecznych, t. 1, red. A. Chabiera, A. Dąbrowski, A. Fortuna-Marek, A. Kozioł, M. Lubaś, P. Nowak, B. Skaldawski, K. Stępnik, Warszawa-Kraków.

Global Heritage Fund (2020), Heritage is Hope in a Time of Crisis, https://globalheritagefund.org/ 2020/03/17/heritage-is-hope-in-a-time-of-crisis/.

Gorzelak G., Rok J., Wojnar K. (2018), Ku zrównoważonemu rozwojowi polskich miast, „Przegląd Polskiego Komitetu do spraw UNESCO”, s. 69-81.

Halme A., Mustonen T., Taavitsainen J., Thomas S., Weij A. (2018), Heritage is Ours. Citizens Participating in Decision Making, Helsinki. 
Hryniewicz J. (2004), Polityczny i kulturowy kontekst rozwoju gospodarczego, Warszawa.

International Council of Monuments and Sites ICOMOS (2019), Climate Change and Cultural Heritage Working Group. 2019. The Future of Our Pasts: Engaging Cultural Heritage in Climate Action, https://indd.adobe.com/view/a9a551e3-3b23-4127-99fd-a7a80d91a29e.

Janikowski R., Krzysztofek K. (red.) (2009), Kultura a zrównoważony rozwój. Środowisko, ład przestrzenny, dziedzictwo, Warszawa.

Kern P. (2020), Artists and culture to imagine the way out of the crisis, https://keanet.eu/artists-andculture-to-imagine-the-way-out-of-the-crisis/.

Kobyliński Z. (2011), Czym jest, komu jest potrzebne i do kogo należy dziedzictwo kulturowe?, „Mazowsze. Studia Regionalne. I. Analizy i Studia”, nr 7, s. 21-46.

Komisja Europejska (2019), Natural and Cultural Heritage in Europe: Working Together within the Natura 2000 Network, https://ec.europa.eu/environment/nature/natura2000/management/pdf/ Natural_and_Cultural_Heritage_report_2019_WEB.pdf.

Kozak M. (2009), Turystyka i polityka turystyczna a rozwój: między starym a nowym paradygmatem, Warszawa.

Krzysztofek K. (2009), Kapitał przyrodniczo-kulturowy Polski jako zasób zrównoważonego rozwoju, w: Kultura a zrównoważony rozwój. Środowisko, ład przestrzenny, dziedzictwo, red. R. Janikowski, K. Krzysztofek, Warszawa.

Lowenthal D. (1998), The Heritage Crusade and the Spoils of History, Cambridge.

Maslow A.H. (1943), A Theory of Human Motivation, „Psychological Review”, nr 50 (4), s. 370-396.

Michalska A. (2002), Psychospołeczne więzi z miejscem zamieszkania na przykładzie wybranych osiedli łódzkich i wsi Brudzewice, „Studia Regionalne i Lokalne”, nr 1 (8), s. 79-100.

Ministerstwo Kultury i Dziedzictwa Narodowego (2019), Programy Ministra 2019. Ochrona zabytków, http://www.mkidn.gov.pl/pages/strona-glowna/finansowanie-i-mecenat/programy-ministra/programy-mkidn-2019/ochrona-zabytkow.php.

Murzyn M. (2002), Dziedzictwo kulturowe a rozwój miasta, „Zeszyty Naukowe AE w Krakowie”, nr 587, s. 65-80.

Myczkowski Z. (2009), O potrzebie zintegrowanej ochrony środowiska kulturowego i przyrodniczego, w: Kultura a zrównoważony rozwój. Środowisko, ład przestrzenny, dziedzictwo, red. R. Janikowski, K. Krzysztofek, Warszawa.

Narodowy Instytut Dziedzictwa (2020), https://dane.gov.pl/dataset/1130.

Nocca F. (2017), The Role of Cultural Heritage in Sustainable Development: Multidimensional Indicators as Decision-Making Tool, „Sustainability”, nr 9, s. 1-28.

Organizacja Narodów Zjednoczonych (1987), Our Common Future: Report of the World Commission on Environment and Development - Brundtland Report, http://www.un-documents.net/ our-common-future.pdf.

Pietrasiewicz T. (2016), Drewniany Skarb. Chroniąc dziedzictwo, kreujemy przyszłość, w: Drewniany Skarb. Chroniąc dziedzictwo, kreujemy przyszłość, Ośrodek „Brama Grodzka -Teatr NN”, Lublin.

Potoczek A. (2000), Dziedzictwo historyczno-kulturowe jako czynnik rozwoju lokalnego i regionalnego, $\mathrm{w}$ : Instytucje kulturalne i stowarzyszenia regionalne $w$ nowych warunkach rozwoju społeczno-gospodarczego Polski. Materiały z konferencji przedkongresowej, red. S. Kunikowski, Włocławek.

Purchla J. (2000), Dziedzictwo a rozwój, w: Dziedzictwo a rozwój. Doświadczenie Krakowa, Międzynarodowe Centrum Kultury, Kraków.

Purchla J. (2014), Dziedzictwo kulturowe a kapitał społeczny, w: Dlaczego i jak w nowoczesny sposób chronić dziedzictwo kulturowe?, red. A. Rottermund, Warszawa. 
Skaldawski B. (2017), Problematyka definicji dziedzictwa, w: Dziedzictwo kulturowe w badaniach. Polacy wobec dziedzictwa. Raport z badań społecznych, t. 1, red. A. Chabiera, A. Dąbrowski, A. Fortuna-Marek, A. Kozioł, M. Lubaś, P. Nowak, B. Skaldawski, K. Stępnik, Warszawa-Kraków.

Siniecka A., Bogacka E. (2018), Dziedzictwo kulturowe województwa wielkopolskiego w świetle danych Narodowego Instytutu Dziedzictwa, „Przykład Zabytków Nieruchomych. Rozwój Regionalny i Polityka Regionalna", nr 44, s. 53-66.

Smith L. (2006), Uses of Heritage, Routledge (e-book).

UNESCO (1972), Konwencja w sprawie ochrony światowego dziedzictwa kulturalnego i naturalnego, https://www.unesco.pl/fileadmin/user_upload/pdf/Konwencja_o_ochronie_swiatowego_dziedzictwa.pdf.

Zubrzycki G. (2017), Traces and Steps: Expanding Polishness through a Jewish Sensorium, w: National Matters. Materiality, Culture and Nationalism, red. G. Zubrzycki, Stanford. 
